Göllner, András B. "Reflections on the Polanyis' Mystique: A Review Article of Gareth Dale. Karl Polanyi: A Life on the Left. New York: Columbia UP. 2016 and Judit Szapor. A világhírü Polányiak: Egy elfelejtett család regényes története (Those World Famous Polanyis: Tales of a Long Forgotten Family). Budapest: Aura kiadó. 2017." Hungarian Cultural Studies. e-Journal of the American Hungarian Educators Association, Volume 12 (2019) DOI: $10.5195 /$ ahea.2019.354

\title{
Reflections on the Polanyis' Mystique: A Review Article of Gareth Dale. Karl Polanyi: A Life on the Left. New York: Columbia UP. 2016 and Judit Szapor. A világhírü Polányiak: Egy elfelejtett család regényes története (Those World Famous Polanyis: Tales of a Long Forgotten Family). Budapest: Aura kiadó. 2017.
}

\section{András B. Göllner}

Abstract: The Polanyis came to prominence in the capital cities of the Austro-Hungarian Empire (Vienna and Budapest) when words mattered, culture was not a four-letter word and Austro-Hungary was territorially the second-largest and the third most populous entity in Europe. The review examines how two recent biographies about members of the Polanyi family treat their protagonists and the forces that shaped their lives after the collapse of the Austro-Hungarian Empire.

Keywords: Austro-Hungary, the linguistic turn, capitalism, feminism, socialism, Karl Polanyi, Michael Polanyi, Laura Polanyi

Biography: András B. Göllner is a Political Economist (PhD, The London School of Economics) and Emeritus Associate Professor of Political Science at Concordia University, Montreal. He is the author of three books, numerous refereed scholarly articles, and appears frequently in the mass media (LA Times, The Huffington Post, The National Post, The Gazette, etc.) He has two books forthcoming in 2019. One is a biography of Ilona Duczynska (the wife of Karl Polanyi), the other is a collection of essays on the 1919 Hungarian Commune. His current research interest is on cyber-Capitalism and its impact on political discourse.andrew.gollner@concordia.ca

What is it about those Polanyis that compels historians to dedicate their lives to analyzing their lives and times? Peter Drucker, a man who knew many of the Polanyis, gives us one of the better answers to this question:

The Polanyis were the most gifted family I have ever known or heard of. What made them truly remarkable was, that all of them enlisted in the same cause: to overcome the nineteenth century, and to find a new society that would be free and yet not 'bourgeois' or 'liberal;' prosperous and yet not dominated by economics; communal and yet not a Marxist collectivism. Each of them, the father, five children [there were actually six children, ABG] and the mother as well went his or her own quite separate way, but each in search of the same goal. They reminded me of the Knights of the Round Table, setting 
Göllner, András B. "Reflections on the Polanyis' Mystique: A Review Article of Gareth Dale. Karl Polanyi: A Life on the Left. New York: Columbia UP. 2016 and Judit Szapor. A világhírü Polányiak: Egy elfelejtett család regényes története (Those World Famous Polanyis: Tales of a Long Forgotten Family). Budapest: Aura kiadó. 2017." Hungarian Cultural Studies. e-Journal of the American Hungarian Educators Association, Volume 12 (2019) DOI: $10.5195 /$ ahea.2019.354

out in search of the same Holy Grail, each in a different direction. I know of no family that was so successful, measured by the standards of the world (Drucker 1978: 126-7).

Judit Szapor, a Canadian-Hungarian historian who teaches at Montreal's McGill University, and Gareth Dale, who teaches politics at London's Brunel University, have spent the better part of the past three decades trying to penetrate the Polanyi family's mystique and their worldwide public appeal. Their conclusions will satisfy many, although not all Polanyi fans. The most disappointed will be those who consider Michael Polanyi (1891-1976), chemist, physicist, philosopher, as the most gifted of the six children of the two wandering Jews, Mihály Pollacek and Cecilia Wohl. Michael Polanyi's thoughts and actions are largely ignored by both of the studies under review, but especially by Judit Szapor's, which promises on its cover a full portrait of this "world famous but long-forgotten family." (Szapor's work is the best illustration of why one should not judge a book by its cover.) For two well-informed biographies of Michael Polanyi, I recommend Getwick (1991) and Nye (2011).

The Polanyis came to prominence in the capital cities of the Austro-Hungarian Empire cities that gave birth to "the linguistic turn," a movement that turned art, philosophy, and the social sciences on their heads after the start of the twentieth century and opened the door to the postmodern view of reality (Rorty 1967 and Toews 1987). Many of the pioneers of this movement were close associates of Karl Polanyi and his wife. The Polanyis retained a lifelong fascination with the role of communications in the processes of deciding who gets what, when and how in a community (Nyiri and Fleissner 1999).

Before its final collapse in 1934, Red Vienna (Gruber 1991) also had a powerful effect on the thoughts and actions of those Polanyis who lived in that city from 1920 until 1934 (McRobbie and Polanyi Levitt 2006). Under the uninterrupted leadership of its Social Democratic municipal governance, Vienna, unlike Budapest, rose out of the ashes of WWI like a phoenix. It was overrun by migrant Hungarian intellectuals including Karl Polanyi, Ilona Duczynska, Béla Balázs, Arthur Koestler, Karl Mannheim, Oscar Jászi, the Communist and Social Democratic leadership of the Commune and thousands of others fleeing the White Terror and the first anti-Jewish laws enacted in Europe by Admiral Nicholas Horthy's government after it came to power in Hungary in August 1919 (Congdon 1991). Gareth Dale shows us how Karl Polanyi came to conclude that neither Liberalism nor Marxism is up to the challenge of managing political-economic change in societies that are in the process of increasingly rapid and complex technological change (Polanyi 1957).

This is the main reason why Polanyi is so relevant today, as we enter the age of artificial intelligence. Karl Polanyi's greatest merit lies in his ability to see through the "structures of magic," the smokescreen that surrounds the alleged wisdom of the invisible hand of the unregulated market mechanism. Unlike Marx, Polanyi had hindsight to build on. He recognized that (all things remaining equal) the most likely consequence of Capitalism is not Socialism, but Fascism. Fascism came to the industrial heartland of Europe, to Germany, Italy and their economic peripheries, such as Hungary, not by accident but by the logic of the invisible hand and by that hand's arms-length relationship with social justice and societal needs. Karl Polanyi taught us that the invisible hand of the market is not unbiased: it is an instrument of manipulation used by the strong against the weak. He wanted us to recognize that in an increasingly interdependent 
Göllner, András B. "Reflections on the Polanyis' Mystique: A Review Article of Gareth Dale. Karl Polanyi: A Life on the Left. New York: Columbia UP. 2016 and Judit Szapor. A világhírü Polányiak: Egy elfelejtett család regényes története (Those World Famous Polanyis: Tales of a Long Forgotten Family). Budapest: Aura kiadó. 2017." Hungarian Cultural Studies. e-Journal of the American Hungarian Educators Association, Volume 12 (2019) DOI: $10.5195 /$ ahea.2019.354

world, we cannot afford to gamble away our future by delegating uncontrolled power to a mechanism that works "invisibly" and free of any public oversight, or scrutiny. Karl Polanyi fully understood the socially disruptive consequences of "information asymmetry" and the "moral hazards" that flow from them before these concepts entered the dictionary of the economic sciences during the 1970s and 1980s thanks to such Nobel Laureates as George A. Akerlof, Michael Spence or Joseph Stiglitz (Stiglitz 2001). It is this premonition or sensitivity that made The Great Transformation so appealing even to Karl's younger brother Michael, whose conservative political views were often at odds with those of his brother.

Gareth Dale's powerful and thorough account of Karl Polanyi's search for the optimal way to reintegrate the market into the fabric of its host community is careful to give credit to the impact Red Vienna had on his protagonist's approach. Dale is somewhat remiss, however, in not acknowledging the full extent of Polanyi's indebtedness to the cognitive influences of revolutionary Russia. Polanyi’s daughter, the economist Kari Polanyi Levitt, my next door neighbor and friend in Montreal, is an important source of information regarding this omission. Based on first-hand knowledge, she argues that the most important roots of Karl Polanyi's lifelong commitment to socialism reaches back to Russia and to a Russian revolutionary family in Vienna that was headed by Samuel Klatschko, a man her father had known and admired since he was a small boy in Vienna. Samuel Klatschko was married to the childhood friend of Karl Polanyi's mother, Cecilia Wohl. The two families, the Klatschkos and the Pollaceks, formed a very tightly knit unit in Vienna before Karl's father decided to move his family from Vienna to Budapest. Even after moving to Budapest, Karl often visited the Klatschkos in Vienna, as did his cousin, Ervin Szabó, who became the leading anarcho-syndicalist leader of the burgeoning revolutionary movement in Hungary during the first two decades of the twentieth century. "Samuel Klatschko was the unofficial liaison between Russian revolutionaries of all varieties and International Socialist organizations. Trotsky was a frequent visitor. When the Russian revolutionaries came to Vienna for meetings and to purchase Marxist literature, they were provided rest and recuperation by the Klatschko and Pollacek families before returning to Russia.... My father told me that these men made an indelible impression on him as well as on his cousin, Ervin Szabó... It was from Samuel Klatschko that Karl Polanyi acquired his admiration for the Russian Revolutionary Socialists" (Kari Polanyi Levitt in Brie and Thomasberger 2018: 22).

Karl Polanyi's "secret attachment" to Russia's revolutionary past may partly explain why throughout his entire life he was unable to utter any serious criticism of the painful affinity fraud played on the industrial and agricultural workers of the Soviet Empire by the Bolsheviks. This may also explain why Karl Polanyi's much younger brother, Michael, who did not know the Klatschkos as well, had no qualms in criticizing the Bolshevik experiment in the Soviet Union. (Polanyi 1940)

As a biographer of Karl Polanyi, Gareth Dale's greatest virtue resides in his willingness to show us that Polanyi's expertise as a political analyst is far more limited than his knowledge of economics. Dale calls Polanyi's analysis of the Attlee government's behavior in 1945 "delusional" and uses the term "dewy-eyed" in describing Polanyi's life-long inability to see through the affinity fraud perpetuated by the Russian Communist Party upon hundreds of millions of people who were brought under the control of its imperial armies and secret services. 
Göllner, András B. "Reflections on the Polanyis' Mystique: A Review Article of Gareth Dale. Karl Polanyi: A Life on the Left. New York: Columbia UP. 2016 and Judit Szapor. A világhírü Polányiak: Egy elfelejtett család regényes története (Those World Famous Polanyis: Tales of a Long Forgotten Family). Budapest: Aura kiadó. 2017." Hungarian Cultural Studies. e-Journal of the American Hungarian Educators Association, Volume 12 (2019) DOI: $10.5195 /$ ahea.2019.354

Polanyi's silence concerning the execution of Imre Nagy, the agrarian Socialist leader of the 1956 Hungarian uprising, his silence concerning the repression of that uprising by the Soviet Red Army after he had initially welcomed the workers' rebellion as a great act of national liberation and his gushing embrace of the directives of the twenty-second Congress of the CPSU in 1962 stand to this day as evidence of a bias that borders on mysticism.

Like Gareth Dale's portrait of Karl Polanyi, Judit Szapor's portrait of Laura Polanyi, the eldest of the Polanyi children, is also a labor of love (Szapor 2017). Unlike the Dale biography, Szapor's work does not reveal the dirty undergarments of its protagonist. Szapor is not shy to admit that the reason why the title of this Hungarian edition of her earlier English-language study on Laura Polanyi (Szapor 2005) is rather misleading. In publishing this Hungarian edition, she is continuing on with her decades-long crusade to redress the balance of attention directed towards the Polanyi family by Hungarian- and English-speaking writers. She wants us to start paying more attention to the female members of this family. As she puts it, "in writing this book, I was driven by what I may say is a hidden agenda. I wanted to harness the interest shown towards Karl and Michael Polanyi, then John C. Polanyi, whose winning of the Nobel Prize added to their appeal. I wanted to use them as a vehicle to raise the consciousness of English-speaking, North American audiences to the great achievements of some of the women who were active in Hungary's public life at the end of the nineteenth century and the start of the twentieth" (Szapor 2017:7-8, translated by ABG). While Szapor does mention some of the recent studies regarding the life and times of the Polanyi men, she claims that none of these recent works (including Gareth Dale's biography) contain any new material about the family's history (Szapor 2017:8-9). While this last comment of hers is a bit off-handed and unjust towards Dale, there is little doubt that Szapor's work is a very readable work, thoroughly researched and stands as a worthy monument to the memory of Laura Polanyi and some of the heroic Hungarian women who fought for and advanced the cause of women's rights in Hungary more than a hundred years ago.

Laura Polanyi's initial novelty rested on her pioneering ventures before WWI into territories of exploration and expression where Hungarian women would neither dare, nor would they have been allowed to venture according to the conventions and laws of the AustroHungarian Empire. Szapor's study painstakingly explores Laura Polanyi's perilous and daring journey into these forbidden pursuits while offering an explanation of why this premodern feminist living in a male-dominated orbit was compelled to become a pragmatist very early on in life. Instead of remaining single or marrying a socially active intellectual with views that echoed her own, Laura Polanyi quickly married a multi-millionaire industrialist, Sándor Stricker, to whom she remained faithful throughout her life; Stricker would finance her pet projects, her social engagement, in return for the love he desired and the family he wished to establish. For both of them, this was a marriage of convenience. (For many in Laura's circle at the time, her wedding announcement was a tragedy. Not only was she an intellectual powerhouse in her own right before tying herself to Stricker at an early age, she was also the belle of intellectual Budapest. Half of Budapest's eligible intellectual males - married or single - fantasized about her, including her cousin, Ervin Szabó, the man she worked for as a young research assistant. Before she married Karl Polanyi, Ilona Duczynska was also enthralled by Szabó, but that's another story.) 
Göllner, András B. "Reflections on the Polanyis' Mystique: A Review Article of Gareth Dale. Karl Polanyi: A Life on the Left. New York: Columbia UP. 2016 and Judit Szapor. A világhírü Polányiak: Egy elfelejtett család regényes története (Those World Famous Polanyis: Tales of a Long Forgotten Family). Budapest: Aura kiadó. 2017." Hungarian Cultural Studies. e-Journal of the American Hungarian Educators Association, Volume 12 (2019) DOI: $10.5195 /$ ahea.2019.354

Szapor's account of Laura's early work as an educational reformer and activist for women's emancipation in pre-1920 Hungary is rich in detail. Both her original English version (Szapor 2005) and this new Hungarian translation provide us with a thorough view of the parallel tracks (both the personal and the public) that shape the protagonist's life and the manner in which she responds to the challenges she encounters throughout. While the two great Polanyi men, Michael and Karl, leave us with tangible, albeit analytical instruments for shaping the world around us, Laura Polanyi leaves us with an example of how to survive, to fight, to go forward without losing step in a male-dominated world. For decades, she formed the glue that held the Polanyi family together. To mention one example of her important, familial role, her daughter's release from Stalin's prison at the height of The Great Terror is entirely due to Laura's ingenuity and perseverance.

Arthur Koestler's global best seller, Darkness at Noon, (Koestler 1941) was based on the prison experiences in Russia of Laura Polanyi's daughter, Eva Zeisel, whom Koestler had had a crush on since their childhood. (For two somewhat contentious, but informative biographies of Koestler see Cesarani 1998 and Scammel 2009.) Szapor knew and interviewed Eva Zeisel for her book on Laura Polanyi and provides us with a good insider's account of Koestler and Zeisel's relationship, including Zeisel's reluctance to allow Koestler to name her publicly as the person upon whom he had modelled his protagonist. What Szapor (or Koestler's biographers) do not tell us is why Zeisel was so reluctant to allow Koestler to identify her role in his 1941 bestseller. Reading Szapor, or even Dale, one may conclude that the reason may have been due to some kind of left-wing, intellectual solidarity with the Soviet dictatorship. Nothing could be further from the truth.

Here is my explanation why Éva Zeisel was so determined to keep herself out of Koestler's anti-Bolshevik narrative: Laura Polanyi's daughter was a pragmatist rather than an ideologue. Initially, it was the fear that knowledge of her role in Koestler's story may precipitate reprisals against her former friends and colleagues left behind in Russia as well as any possible reprisals that could be committed against family members who would be travelling in the Soviet Union in the future to escape the Nazis (e.g., her mother) that forced Éva to plead for anonymity. From the late 1940s on (including the infamous McCarthy era in the US) it was the fear of being branded a former Communist sympathizer that preyed on her mind. Her reluctance to be identified was the result of survival smarts. She wanted to stay out of the crosshairs of the anticommunist warriors in the US. This is what forced her to keep quiet during the late 1940s and throughout the 1950s.

Laura Polanyi was not only a tiger in defending her own cubs. She fought on behalf of many other family members who found themselves caught up in the turmoil sweeping over Europe and America during and shortly after WWII. Szapor gives us an excellent catalogue of Laura Polanyi's courage and resourcefulness. She cites Karl Polanyi's testimony for example, concerning how he could not have endured in America without his elder sister's support (Szapor 2017: 214).

It is only after these battles have been won in America that Laura can return to her first love: speaking the truth to those in power. Laura Polanyi was approaching the seventh decade of her life when the last chapter of her life began. She became involved in a research project that sought to protect, or preserve the reputation of an American hero, Captain John Smith (of 
Göllner, András B. "Reflections on the Polanyis' Mystique: A Review Article of Gareth Dale. Karl Polanyi: A Life on the Left. New York: Columbia UP. 2016 and Judit Szapor. A világhírü Polányiak: Egy elfelejtett család regényes története (Those World Famous Polanyis: Tales of a Long Forgotten Family). Budapest: Aura kiadó. 2017." Hungarian Cultural Studies. e-Journal of the American Hungarian Educators Association, Volume 12 (2019) DOI: 10.5195/ahea.2019.354

Pocahontas fame), the founder of Virginia in the seventeenth century. (While John Smith is more widely known as the founder of the first permanent English colony in America, the man who held the colony together during times of starvation and disease, Indian attacks and internal dissent, he also travelled through Hungary in the 1600s and wrote about his adventures there.) Laura Polanyi joined forces with the great American historian, Bradford Smith, to preserve the legacy of John Smith and succeeded in doing so by all accounts. As Szapor points out, "This last outburst of her intellectual creativity sustained her for the remaining eight years of her life and provided a final, somewhat ironic twist to her professional life. The Smith Project materialized in more publications than all her previously published works put together as her expertise on the topic was widely recognized" (Szapor 1997).

In conclusion: Szapor and Dale provide us with two of the best recent biographies of Laura and Karl Polanyi respectively. A fully integrated and balanced family history still remains to be written.

\section{Works Cited}

Brie, Michael and Thomasberger, Claus (eds). 2018. Karl Polanyi's Vision of a Socialist Transformation. Montreal: Black Rose Books.

Cesarani, David. 1998. Arthur Koestler: The Homeless Mind. New York: The Free Press, Congdon, Lee. 1991. Exile and Social Thought: Hungarian Intellectuals in Germany and Austria 1919-1933. Princeton, New Jersey: Princeton UP.

Dale, Gareth. 2016. Karl Polanyi: A Life on the Left. New York: Columbia UP.

Drucker, Peter F. 1978. "The Polanyis" in Adventures of a Bystander. New York: Harper and Row Publishers.

Getwick, Richard. 1987. The Way of Discovery: An Introduction to the Thought of Michael Polanyi. Oxford UP.

Gruber, Helmut. 1991. Red Vienna: Experiment in Working Class Culture, 1919-1934., Oxford UP.

Koestler Arthur. 1941. Darkness at Noon. London. Scribner.

Nye, Mary Jo. 2011. Michael Polanyi and His Generation: Origins of the Social Construction of Science. University of Chicago Press.

Nyíri, Kristóf and Fleissner, Peter (eds). 1999. Philosophy of Culture and the Politics of Electronic Networking Vol 1. Austria and Hungary: Historical Roots and Present Developments, Innsbruck-Wien: Studien Verlag / Budapest: Áron.

Polanyi, Karl. 1957. The Great Transformation. Boston. The Beacon Press.

Polanyi-Levitt, Kari and McRobbie, Kenneth (eds). 2006. Karl Polanyi in Vienna. Montreal. Black Rose Books.

Polanyi, Michael. 1940. The Contempt of Freedom. The Russian Experiment and After. London: Watts \& Co.

Rorty, Richard M. (ed). 1967. The Linguistic Turn, Essays in Philosophical Method. Chicago: University of Chicago Press.

Scammel Michael. 2009. Koestler: The Literary and Political Odyssey of a $20^{\text {th }}$ Century Sceptic. New York: Random House. 
Göllner, András B. 'Reflections on the Polanyis' Mystique: A Review Article of Gareth Dale. Karl Polanyi: A Life on the Left. New York: Columbia UP. 2016 and Judit Szapor. A világhírü Polányiak: Egy elfelejtett család regényes története (Those World Famous Polanyis: Tales of a Long Forgotten Family). Budapest: Aura kiadó.

2017." Hungarian Cultural Studies. e-Journal of the American Hungarian Educators Association, Volume 12 (2019) DOI: 10.5195/ahea.2019.354

Stiglitz, Joseph E. 2001. Information and the Change in the Paradigm in Economics. Nobel Prize Lecture. December 8.

Szapor, Judit. 2005. The Hungarian Pocahontas: The Life and Times of Laura Polanyi Stricker, 1882-1959. New York: Columbia UP.

Szapor, Judit. 2017. A világhírü Polányiak: Egy elfelejtett család regényes története ['The World-Famous Polanyis: A Long Forgotten Family's Novel-like History'] Budapest. Aura. Toews, John E. 1987. "Intellectual History after the Linguistic Turn: The Autonomy of Meaning and the Irreducibility of Experience," The American Historical Review, 92:4. 